Proc. Estonian Acad. Sci. Biol. Ecol., 2001, 50, 2, 66-84

\title{
FROM INSECTA, PISCATORIBUS ... NOXIA TO ECOLOGICAL MODELS - HISTORY OF BRACKISH-WATER BIOLOGY IN FINLAND
}

\begin{abstract}
Erkki LEPPÄKOSKI
Department of Biology, Åbo Akademi University, FIN-20500 Turku/Åbo, Finland; eleppakoski@abo.fi

Received 28 March 2001

Abstract. The history of brackish-water biology in the Finnish coastal waters from the Linnaean period to the 1990s is briefly reviewed. The first notes on benthic animals date back to 1769 . Two "insects", Idotea entomon (Oniscus) and Gammarus pulex, were mentioned as causing damage to fishing. Sporadic studies of benthic organisms were started in the middle of the 19th century. In the 1920 s, S. G. Segerstråle began studies of the Fucus belt and soft bottom fauna. A gradual ecologization of brackish-water biology took place.

The 1960s saw a huge increase in the volume and diversity of marine biological studies. The growing environmental awareness resulted in legislative reforms. Applied (environmental) marine ecology now played a significant role. In the 1980s, marine research demonstrated both advances in theoretical ecology and the need to address problems specific to the Baltic Sea through field experiments and studies of recovery from pollution or other forms of disturbance.
\end{abstract}

Key words: history of science, bibliography, Baltic Sea.

\section{INTRODUCTION}

A special session of the 10th Symposium of the Baltic Marine Biologists in 1987, which took place in Kiel, Germany, was devoted to the history of Baltic biological oceanography. Six contributions from this session were published in Kieler Meeresforschungen (Sonderheft 6, 1988). One of them (Haahtela, 1988) identified four scientists whose role in the development of the Baltic Sea biology in the 20th century had been crucial: Sven Ekman (Uppsala, Sweden), Adolf Remane and Carl Schlieper (Kiel, Germany), and Sven G. Segersrtåle (Helsinki, Finland). These scientists will be remembered due to their outstanding 
contributions to the biological research of this area. In fact several, if not most, well-known marine scientists in the Baltic Sea countries can be regarded as their students along the chain of successors. In the same volume, Leppäkoski \& Rönnberg (1988) reviewed the history of benthic studies in the northern Baltic Sea.

The aim of this review is to briefly summarize the research into the biota of the Finnish part of the Baltic Sea and to describe the main trends in the science of brackish-water ecology in Finland from the early naturalists of the Linnaean period to ecological modellers in the 1990s. For more detailed summaries of early studies in the northern Baltic, reviews to be consulted are those by Segerstråle (1957a, 1964a, 1975, 1976), Hällfors et al. (1987), Haahtela (1988), and Leppäkoski \& Rönnberg (1988).

Comprehensive bibliographies covering the years 1953-73 were compiled by Segerstråle (1964a,b, 1975). In an M.Sc. thesis, altogether 920 articles and reports on marine biological research, including fish and fisheries biology, inside Finnish borders were analysed both thematically and geographically (JylhäPyykönen, 1978, 1981). The history of limnology, including brackish-water research, was presented by Luther (1982) and Sarvala (1992). A tool for bibliometric studies of the most recent literature on the Baltic Sea, the Baltic Marine Environment Bibliography (BALTIC - Baltic Marine Environment Database, 2001) covers entries from the year 1970.

This review deals with the northern Central Basin, the Archipelago Sea, the Gulf of Finland, and the Gulf of Bothnia. The main emphasis lies on field studies. Studies on anatomy, morphology, systematics, and physiology of brackish-water organisms are mostly not included. Also research into fish stocks and fisheries remains outside the scope of this paper, even if the main purpose of most early efforts within fish biology was to provide information that may be of importance for the advancement of commercial fishery.

\section{FROM P. A. GADD TO J. A. PALMÉN}

There are a large number of macrobenthic species among the northern Baltic fauna and flora first described by Carolus Linnaeus (or Carl von Linné), from poriferans (Ephydatia fluviatilis) to scyphozoans (Aurelia aurita), crustaceans (Saduria (Mesidothea) entomon, Gammarus locusta), molluscs (Mytilus edulis, Macoma balthica), algae (Fucus vesiculosus, Furcellaria lumbricalis), and tens of fish species. However, it is not known to me whether the specimens studied in the 18th century by Linné and the early Linnaeans in Uppsala originated from northern Baltic waters or not.

In Finland, a chair in economics (mainly applied natural science) was established in 1746 at the old academy in Åbo (Turku), the first university of 
Finland, founded in 1640. The first holder of this chair was Pehr Kalm, who had studied under Linné at Uppsala. He was the internationally best known Finnish representative of the Linnaean period. The first scientific notes on benthic animals of the Finnish part of the Baltic might date back to a thesis published at Academia Aboensis under the supervision of Per Adrian Gadd (1769). In this thesis (Fig. 1), two aquatic "insects", Idotea entomon (Oniscus) and Gammarus pulex, were described as damaging fishing gear. In addition to this work, there was obviously no interest in brackish-water biology among the Linnaean successors in Turku.

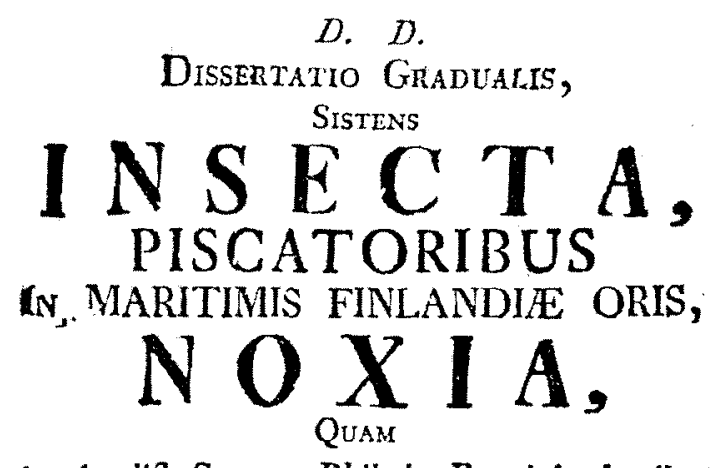

Venia Ampliß. Senat. Pbil. in Reg. |Acad. Aboünfl, P R ES IDE,

DN. PETRO ADRIANO GADD,

Chem. Pror. Reg. \& Ord. Rei. Plant. Direct, Reg. Acad. Scient. Holm. Membro, Rectore h. t. Magnirico.

Publico examini fubmittit Stipendiakus SegerCrantzianus.

CAROLUS NIC. HELLENIUS, Ammanuensis in Labor. Chemico, Tavastia - Fenio,

In AUdit. MAJ. Die XXVI. Junil Annt MDCClXIX.

H. A. A. \$.

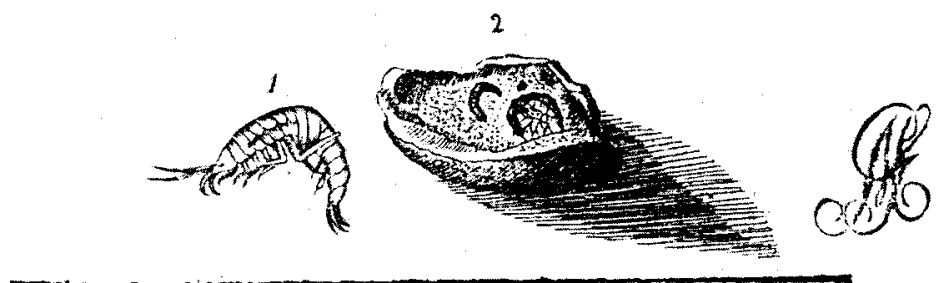

ABOE, Typis JoH. Christoph, FrenCKELI.

Fig. 1. First known notes on brackish-water invertebrates in Finland were published in an academic dissertation in 1769. 
Finnish brackish-water research dates back more than 100 years. Italy, Denmark, and Germany were the first countries to investigate marine life in sea bottom (Rasmussen, 1977) since the middle of the 18th century, i.e. some 130 years earlier than in the northern Baltic. There might be three main reasons for this delay in the north (Leppäkoski \& Rönnberg, 1988). (1) The impoverished fauna and flora of the northern Baltic (salinity generally < 7 PSU) did not evoke enthusiasm among the pioneers of comparative morphology and systematics. (2) There was almost no economic interest in aquatic organisms other than fish in the inner parts of the Baltic. Invertebrates are not harvested due to their small size in diluted brackish water. Harmful benthic species causing trouble in fisheries were already described by Gadd (1769), whereas technical problems and economic losses caused by fouling organisms in power plants were not looked for in a scientific sense before the 1980s (Laihonen et al., 1985). (3) No adequate scientific bodies concerned with biology existed in the area during the 18 th and the first decades of the 19th century.

Studies of benthic organisms in the Gulf of Finland were started in the middle of the 19th century. Siemaschko (1847) reported some bivalves, and there are some sporadic notes from the late 1800 s on crustaceans and molluscs from the western Gulf of Finland up to the Northern Quark (Nordenskiöld \& Nylander, 1856; Cajander, 1869; Levander, 1899, 1901a,b).

In the 1880s, Nordqvist (1890) sampled invertebrates at several localities from the northern part of the Bothnian Bay to the Archipelago Sea and performed some sampling also in the Åland Sea even down to a depth of $230 \mathrm{~m}$. The first Finnish oceanographic expedition to the northern Baltic set out on 30 August 1898 (Hela, 1975).

Early notes on the benthic flora of the Finnish coast of the Gulf of Finland were given by Nylander (1844) and Hisinger (1857). Herbarium Musei Fennici, a plant list compiled by Nylander \& Saelan (1859), included the first records of macroalgae in Finland. Strömfelt (1884) published notes on 29 macroalgal species recorded in the Archipelago Sea, while Krok (1869) was the first to study algae in the Åland area.

Starting with merely faunistic and floristic studies, the investigations were directed towards biocoenology in the first decades of the 20th century, in an attempt to demonstrate the affinity of organism species to one another. Causal relationships were documented between species assemblages and the most important environmental factors and gradients (water depth, type of bottom, and since the early 1900s also salinity). Consequently, a gradual "ecologization" of brackish-water biology took place; the term ecology was used first among botanists around 1900 (Söderqvist, 1986; Leppäkoski \& Rönnberg, 1988).

In the late 1800s, some biologists at Helsinki University (successor of the old academy in Åbo, moved to Helsinki in 1828; the only university in Finland until 1918) focused their interest upon brackish-water biota. Professor J. A. Palmén was Finland's leading zoologist during several decades and became the main 
protagonist of Darwinism in Finland (Leikola, 1980). At the university hydrobiology was, until 1888, taught only indoors (Luther, 1982). Palmén worked actively for 30 years, until his death in 1919, to create a field base for studies in brackish-water zoology. He became further inspired by his visits to Naples (1876), Bergen (1881), and Rostock (1891). A modest summer laboratory was established in 1889 on Esbo-Lövö, an island in the vicinity of Helsinki. This island served as a base for Palmén and a group of young zoologists, with Palmén's assistant K. M. Levander as an active leader, until 1899 (for publications from Esbo-Lövö see Luther, 1957).

Tvärminne Zoological Station was founded by Palmén with his private means in 1902 and donated in his will to Helsinki University (Leikola, 1980). This was the starting point of more systematic investigations of fauna and flora in the entrance area of the Gulf of Finland. Häyrén (1900) was the first to describe the zonation of the Tvärminne area both biologically and geographically. During the first 50 years of Tvärminne's history, some 370 papers were published, covering virtually all the important taxonomic groups, both aquatic and terresterial, in the area (see Luther, 1957 for a bibliography). Before World War I, the benthic groups studied at Tvärminne included Turbellaria (A. Luther), Nematoda (G. Schneider), Nematomorpha (K. M. Levander), Oligochaeta (Levander, E. Munsterhjelm, D. Toivonen), Ostracoda (N. Hirschmann), Decapoda (Levander), Hemiptera (H. Lindberg), Trichoptera (A. J. Silfvenius/Siltala), Coleoptera (Lindberg), Mollusca (Levander, Luther), and algae (E. Häyrén, C. Skottsberg).

Rock pool research was in focus since the late 1800s; in fact, Levander's (1900b) classification of rock pools has been regarded as the first ecosystemoriented contribution to hydrobiology in Finland (Luther, 1982). Research into rock pool ecophysiology (e.g., Wikgren, 1952; Lagerspetz, 1955; Reuter, 1961) has been continued until our days.

The research work of the pre-war generation of early ecologists tended to answer the questions "What?" and "Where?". If one wants to answer these most elementary questions today, he still has to go to very sporadic written sources of local character and back to the authors mentioned above from the early years of the 20th century.

\section{THE INTER-WAR PERIOD}

Development of quantitative and semi-quantitative sampling methods enhanced the synecological analysis of plant and animal communities. These studies, together with studies in marine biogeography, characterize the Baltic Sea biology during the inter-war period. The number of biologists involved in brackish-water ecology in the northern Baltic area was still rather small during these decades (see Välikangas, 1933 for a review). In Finland, S. G. Segerstråle started in 1922 
his studies of the invertebrate fauna of the Fucus vesiculosus belt and soft bottoms (Segerstråle, 1928, 1933a,b, 1937). Segerstråle became the leading researcher in northern Baltic marine biology. He was a true Baltic biologist: of his about 100 publications 85 deal with the Baltic Sea (Haahtela, 1988). Segerstråle's research topics included population dynamics (recruitment, age, growth, fluctuations in abundance and biomass) in relation to environmental factors of Macoma balthica, and of the amphipods Monoporeia (Pontoporeia) affinis, P. femorata, and Corophium volutator (Segerstråle, 1927, 1933a,b, 1937; Haahtela, 1988; Leppäkoski \& Rönnberg, 1988). Hellén (1919a,b) published notes on isopods and amphipods. Turbellarians were the object of a long series of studies, started by Luther (1904 and later) and Karling (1931 and later). On the Finnish coast of the Gulf of Finland, Ulvinen (1937) studied macrophytes in the Kotka archipelago. The inner limits of marine algae in the gulfs of Bothnia and Finland were recorded by Häyrén (e.g. 1928, 1931, 1938) and Välikangas (1933).

The studies of impacts of pollution upon the Baltic Sea biota were largely neglected in Finland until the 1960s (see below). However, Häyrén (1910, 1921, 1923 , and later) was an early pioneer and the first to use macrophyte and algal associations as indicators of pollution. His saprobic system and classification of polluted coastal waters was based on the system of Kolkwitz \& Marsson (1902), developed for running waters in Central Europe. The investigations of Häyrén off Helsinki and in other areas have been repeated several times until recently. Häyrén (1921) published the first substantial contribution to applied brackishwater biology in Finland. Written mainly in Swedish and published in series of limited distribution, his important works remained little known outside the Nordic countries (Luther, 1982; see Hällfors et al., 1987 for a comprehensive review).

There were also several studies of plankton carried out in eutrophicated waters in the Helsinki sea area in the early 1900s and during the inter-war period. Studies of Klingstedt (1907), Levander (1913), and Välikangas (1926) clearly demonstrated changes in planktonic communities caused by sewage in the archipelago waters (Niemi, 1972b).

\section{POST-WAR EXPANSION AND DIVERSIFICATION OF BRACKISH-WATER BIOLOGY}

A few studies only were published by Finnish researchers during the first 10-15 years after World War II, among them some comprehensive monographs. Since the early 1930s, Lindberg $(1937,1948)$ studied the aquatic insect fauna of the upper littoral along the Finnish, Swedish, and Estonian coasts from the Bothnian Bay to the Sound. Palmén (1955) focused on chironomids, Segerstråle (1944, 1950) continued his studies on soft-bottom fauna, Purasjoki (1953) his 
work on zooplankton, and Luther (1951a,b) finished his comprehensive studies on macrophytes along salinity gradients by Tvärminne, started in the 1930s but interrupted by the war. Even if most hydrobiologists of this period were more interested in descriptive studies than in causalities, the Tvärminne school raised international attention by relating faunistic and floristic descriptions to environmental variables that were measurable in the 1950s and 1960s. For instance, the molluscan fauna in relation to salinity gradients in the Tvärminne area was studied by Koli (1961).

Research into the biogeography of the Baltic Sea centred on the post-glacial immigration of its organisms, verified largely through studies of benthic and nekto-benthic fauna and exemplified by crustacean species such as M. affinis, P. femorata, Mysis mixta, M. relicta, and Saduria entomon, and the priapulid Halicryptus spinulosus (Segerstråle, 1957b, see Segerstråle, 1982 for a review).

For some reason, there is a gap for 40 years in the benthos research in the Gulf of Finland after Knipovich (1909) until the first sampling trips were undertaken by the Finnish research vessel Aranda in the mid-1950s (Sjöblom, 1955). Only two notes on the benthic fauna of the Bothnian Bay are known from the period between Nordqvist (1890) and Lindberg (1948); all early records were summarized by Haahtela (1964).

In the 1960s there was a huge increase in biological studies of Finnish coastal waters (Fig. 2). New approaches, methods, and ecological concepts were adopted

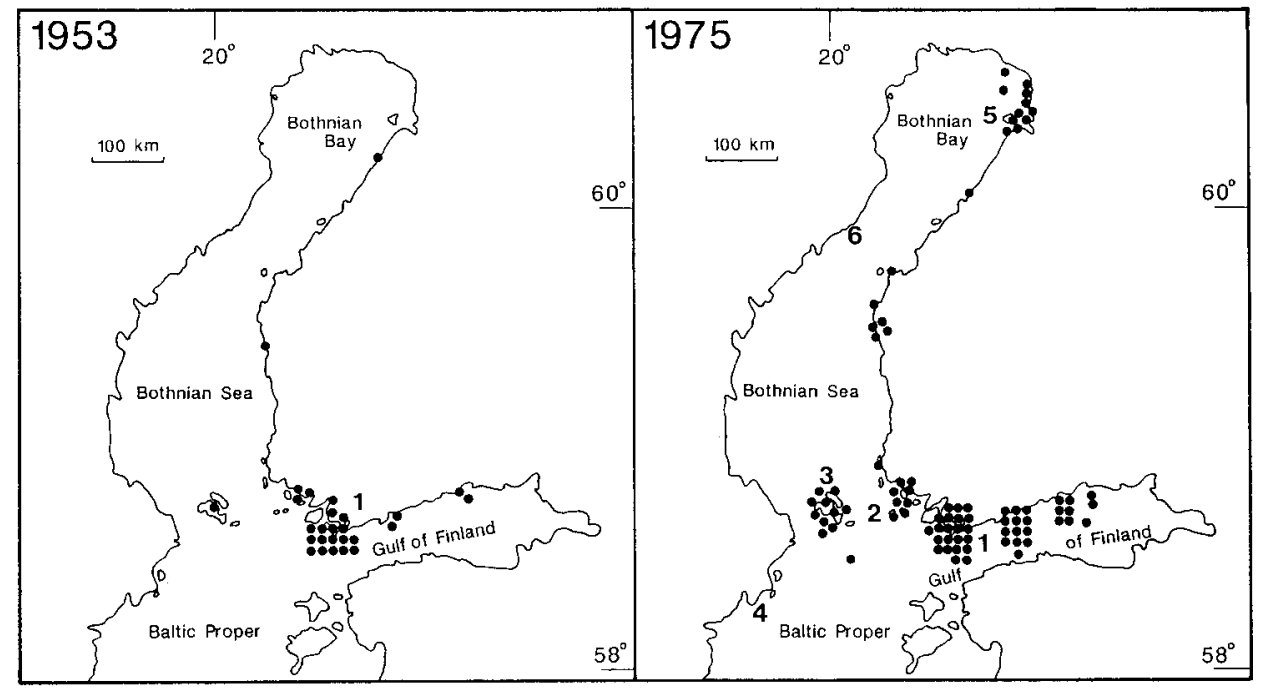

Fig. 2. Geographical distribution of studies on phyto- and zoobenthos in Finland in 1953 and 1975 (redrawn from Jylhä-Pyykönen, 1978 and Leppäkoski \& Rönnberg, 1988), and the location of biological field stations founded before the 1950s ( $1=$ Tvärminne Zoological Station) and after the late 1950s (2 = Archipelago Research Institute; 3 = Husö Biological Station; 4 = Askö Laboratory; 5 = Bothnian Bay Research Station; 6 = Norrby Laboratory). 
at an increasing rate (see Segerstråle, 1964b, 1976; and Andersin et al., 1978 for reviews). There are some apparent reasons for this expansion (Leppäkoski \& Rönnberg, 1988). New universities and new field stations were founded (Fig. 2) and positions opened for marine biologists. A new chair in ecology, specializing on the Baltic Sea, was established at the University of Helsinki in 1974. In the same year, Åbo Akademi University established a professorship in ecology and environmental protection in coastal and archipelago areas. The increasing awareness of eutrophication and other environmental problems resulted in administrative and legislative reforms. National and local water authorities and water courts were established. An applied and environmental approach to marine ecology now played a significantly greater role than in the pre-war years.

The Finnish Institute of Marine Research (Helsinki, established in 1918 as a governmental research institute) undertook continuation of the studies carried out by the Hydrographical-Biological Research Unit, administrated by the Societas Scientiarum Fennica (Finnish Society of Sciences and Letters). Biological studies remained, however, under the auspices of the Society until the late 1950s (Sarvala, 1992).

Activities of the Fisheries Division of the Game and Fisheries Research Institute in Helsinki and its field stations along the coast have largely contributed to the basic and applied fish biology in Finland. Other governmental institutions involved in biological research of Finnish coastal waters are, e.g., the Finnish Centre for Radiation and Nuclear Safety (Ilus, 1996) and the Finnish Environment Institute (Kangas, 1996). The Water Conservation Laboratory of the City of Helsinki started operation in the 1960s, focussing mainly on the production biology in the waters around Helsinki (Lehmusluoto \& Pesonen, 1973; Melvasalo et al., 1975).

During the first half century of Finnish marine biology, the dominating role of Tvärminne Zoological Station was evident. In the 1950s, over 90\% of all published studies (including M.Sc. theses) emanated from the University of Helsinki (Jylhä-Pyykönen, 1981). In the 1950s and 1960s, new facilities became available for field and laboratory studies in brackish-water biology. Three new field stations were established to serve as bases for biological sampling, experimental studies, field courses, and training of young scientists (Fig. 2). These are the Archipelago Research Institute (University of Turku; Lohm Biological Station founded in 1958, the Institute in 1963), Husö Biological Station (Åbo Akademi University; founded in 1959 on the Åland Islands) and Perämeri Research Station (University of Oulu; the first field base was opened in 1962 in the innermost Bothnian Bay).

Working at these new field stations, in the 1960s some pioneers contributed much towards the knowledge of, e.g., benthic diatoms (Rautiainen \& Ravanko, 1972), which had earlier been studied in the Tvärminne area only by Mölder 
(1943). The stucture of macroalgal communities was studied at several places between the Finnish mainland and the Åland Islands (Mathiesen, 1965; Ravanko, 1968, 1972; Rönnberg, 1975, 1981). The first quantitative studies on soft-bottom macrofauna in the Archipelago Sea were undertaken by Tulkki (1960) and his students (Bagge et al., 1965).

When looking for the early beginnings of plankton research we have to go to the works on phytoplankton and mesozooplankton of Levander (1891, 1900a, 1915), Levander \& Purasjoki (1947), and Leegaard (1920). First notes on the plankton in the Bothnian Bay were published by Wuorentaus (1913). Välikangas (1926) and Halme $(1944,1958)$ were the real pioneers for brackish-water planktology in Finland (see Niemi (1973) for a comprehensive list of publications). Finnish research work related to pelagic production, i.e., phytoplankton, primary production, chlorophyll, and biomass, increased markedly in the 1960s, especially when the ${ }^{14} \mathrm{C}$ method was taken into use (e.g., Lassig \& Niemi, 1973); by $1963-$ 72 about 100 papers on these topics were published (Segerstråle, 1976). One of the most valuable contributions to planktology in the 1970s is that of Niemi (1973, 1975), who studied the transition area from fresh to brackish water by Tvärminne with regard to nutrients, phytoplankton, and primary production throughout the year.

Studies of mesozooplankton dynamics did not become a major issue in Finnish brackish-water biology prior to the 1970s (Vuorinen \& Ranta, 1987; Viitasalo, 1992). However, the works of Lassig (1965) and Sarvala (1971) constituted valuable contributions to the ecology of meroplanktonic larvae of benthic organisms (bivalves and the polychaete Harmothoe sarsi, respectively).

The scientists trained in zoology and botany began successively to promote ecology as an autonomous branch of natural sciences (Söderqvist, 1986). During this period of expansion in marine biological research, zoology and zooecology maintained their dominating role in Finnish brackish-water biology. Of 670 papers published in 1953-75, 77\% dealt with zoology and 23\% with botany (JylhäPyykönen, 1978). Until the 1990s, most brackish-water ecologists in Finland were men. Among the 100 Finnish authors mentioned in the list of references for this review, only 15 are female scientists.

\section{INTERNATIONALIZATION OF FINNISH MARINE BIOLOGY}

A. J. Malmgren (1834-97) was the first marine and fishery biologist in Finland. In the 1860s, he participated in two of A. E. Nordenskiöld's expeditions to Svalbard (Spitzbergen). His successor O. Nordqvist was with the famous Vega expedition in 1878-79 (Wikgren, 1966).

Marine research is inherently an internationally oriented field of science. For the early marine and brackish-water biologists, the choice of the Baltic as a study 
area was natural. The only attainable oceanic sea coast was a narrow strip of coast, the Petsamo area, between Norway and Russia on the Arctic Ocean, belonging to Finland from 1921 until the end of World War II. In 1957, the Finnish R/V Aranda undertook an expedition to the Barents Sea.

The Baltic Sea was included in the cooperative work of the International Council for the Exploration of the Sea (ICES) from the start of the organization in 1902. However, the international contacts within marine biology did not become intensive until the late 1960s. Several scientific or administrative bodies were founded in order to facilitate international cooperation. In 1968, the organization Baltic Marine Biologists (BMB) and its first working groups were established (Segerstråle, 1976). The biannual BMB symposia became an important forum for exchange of scientific information within the Baltic area and created new contacts between west and east. Since the first BMB symposium in Rostock, Germany, in 1968, 16 BMB symposia have been held, in which more than 1300 scientific papers have been presented, and 16 symposium proceedings volumes have been published. The BMB has cooperated with the Helsinki Commission (HELCOM 1974 - ), especially on standardization of sampling methods.

In 1971, ICES and the Special Committee on Oceanic Research (SCOR) established a Working Group on the Study of Pollution of the Baltic. In 1968-72, bilateral commissions for the gulfs of Finland and Bothnia were established between Finland and the USSR and Finland and Sweden. These commissions coordinated sampling programmes and arranged several scientific symposia.

The Nordic cooperation in marine biology was strenghtened considerably when the Nordic Council for Marine Biology (NKMB) was established in 1957. Through participation in Nordic Ph.D. courses and exchange programmes young scientists came into contact both with one another and research facilities available in the Nordic countries. A special NKMB grant was available for postgraduate studies in Miami, Florida.

At Tvärminne and Krunnit (Bothnian Bay), the dynamics of the most important littoral ecosystems was studied as a part of the International Biological Programme - Marine Productivity (IBP-PM), started in 1968 (Haahtela, 1970; Niemi, 1973; Hällfors et al., 1975; Luther et al., 1975).

Individual Finnish biologists worked at universities and biological stations mainly in the Nordic countries. Work in the Bornholm Basin (southern Baltic) by Tulkki $(1965)$ and Leppäkoski $(1969,1971)$ demonstrated the shifts in zoobenthos during periods of anoxia and recolonization. Haahtela studied ecology of the Jaera albifrons group (Isopoda) in Britain (Naylor \& Haahtela, 1966) and on the Skagerrak coast of Sweden (Naylor \& Haahtela, 1967). Staying at Kristineberg Zoological Station on the Swedish west coast, Bagge (1969) and Leppäkoski (1975) carried out zoobenthos studies in some polluted fjords along the Skagerrak coast. 


\section{INCREASE IN RESEARCH INTO POLLUTION AND EUTROPHICATION}

Concern for the environmental condition of the Baltic Sea - and the awareness of ecological risks - increased markedly in the late 1960s and early 1970s, i.e., before and after the UN World Conference on the Human Environment, held in Stockholm in 1972. Towards the end of the 1970s and, especially, in the 1980s the quantitative expansion and further diversification of marine biological research continued in Finland. New methods and approaches were adopted in research demonstrating both advances in theoretical ecology and the need to solve environmental problems specific to the Baltic Sea.

Using "Finland" as a key word, a search on the Baltic Bibliography (BALTIC - Baltic Marine Environment Database, 2001) gave, in average, the following number of entries per year:

$$
\begin{array}{rr}
1970-80 & 70 \\
1981-90 & 125 \\
1991-98 & 135
\end{array}
$$

This increase is, in part, due to new fields of pollution research introduced in the 1960s and 1970s. Studies on eutrophication (Fig. 3) and pollution were performed by water authorities, water pollution control associations, and private consultants (Sarvala, 1992) but also by university scientists. Chemical pollution

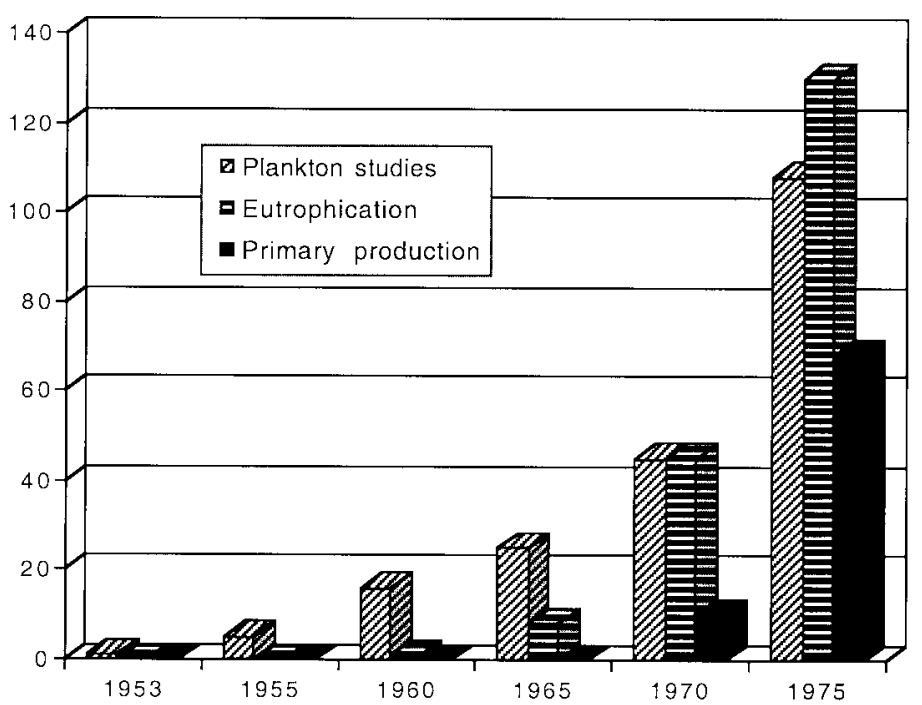

Fig. 3. Cumulative number of papers related to eutrophication, planktology, and primary production in Finnish coastal waters published in 1953-75 (redrawn from Jylhä-Pyykönen, 1978). 
monitoring of the Baltic Sea acquired a more regular form in 1964 (Sarvala, 1992). About 30 studies published in 1953-75 focused on environmental chemicals (especially mercury) and their effects on brackish-water organisms; the first paper related to mercury is from 1968 (cf. Jylhä-Pyykönen, 1978). Some innovations in marine pollution research for this period are presented in Table 1.

Table 1. Examples of research into pollution problems in Finnish coastal waters in the 1960s-80s

\begin{tabular}{l|l}
\hline Purpose of the study & References \\
\hline
\end{tabular}

Soft-bottom fauna as indicator of pollution

Body burdens of environmental pollutants in selected species

Combined monitoring of phytoplankton, primary production, and nutrient dynamics in eutrophicated coastal waters

Effects of toxicants on phytoplankton assimilation Effects of oil spills (the earliest ones being related to the Palva disaster in 1969)

Effects of oil refinery effluents; ecotoxicological testing of pollutants in model ecosystems (microand mesocosms)

Toxicity of oil dispersants

Radioactive contamination in benthic animals Impacts of coastal engineering works

Effects of ships' waves on macroalgal associations Studies of recolonization subsequent to the elimination of pollution or other forms of disturbance

Field experiments, e.g., colonization studies Invasive history of nonindigenous species*

Toxic algae
Tulkki, 1964, 1969; Laakso, 1965; Bagge \& Voipio, 1967; Särkkä, 1967; see Leppäkoski, 1975 for a review

Aho, 1968; Järvenpää et al., 1970; Linko et al., 1974

Niemi, 1973; see Sarvala, 1992

Niemi, 1972a

Pelkonen \& Tulkki, 1972; Leppäkoski, 1973; Mankki \& Vauras, 1974

Leppäkoski \& Lindström, 1978

Lindén, 1974

Bagge \& Salo, 1967

Bonsdorff et al., 1984

Fagerholm, 1975; Rönnberg, 1975

Bonsdorff, 1980

Bonsdorff \& Österman, 1985

Karppinen \& Kairasuo, 1961; Leppäkoski, 1984

Persson et al., 1984

* Introduction for stocking purposes of lobster, crabs, and blue shells from Denmark to the Finnish an Estonian coasts was planned as early as in the mid-1700s (Hamel, 1852). Delivery of settlings failed, however, and further efforts were questioned because of the low salinity of our waters. 


\section{CONCLUDING REMARKS}

Most scientists belonging to the present-day generation of brackish-water biologists are looking for answers to the questions of crucial importance in Baltic Sea biology: "Why?" and "How?" The first "why's" were stated by Lindström (1855) and Krok (1869) and their contemporaries who realized the importance of salinity and depth gradients (Leppäkoski \& Rönnberg, 1988).

The last "how's" will never be answered. Mechanisms regulating interspecific relationships and environmental factors, both abiotic and biotic, influencing the structure and function of different subsystems, are intensively studied in all parts of the Baltic Sea. The ecosystem approach was adopted by the Askö school at Stockholm University in the early 1970s (Jansson, 1972).

The mathematically and theoretically sophisticated methods continued to strenghten. The outcome from this work is today expressed as ecosystem models and verified through experimental work with model ecosystems. During the last 10-15 years, the shift from descriptive to experimental studies has become apparent from the increasing interest in the study of trophic interactions, in which the whole brackish-water ecosystem is to be taken into consideration (e.g., Bonsdorff et al., 1990; Fig. 4).

The history of systematic research into brackish-water biota in Finland covers a period of more than 100 years. Therefore, syntheses and reviews of what has been done and achieved by generations of biologists are at least as valuable as the publishing of primary data (Haahtela, 1988). The work carried out by early natural historians, inter-war autecologists, and post-war synecologists forms an important knowledge base for recent experimentalists and modellers as well as for future brackish-water research.

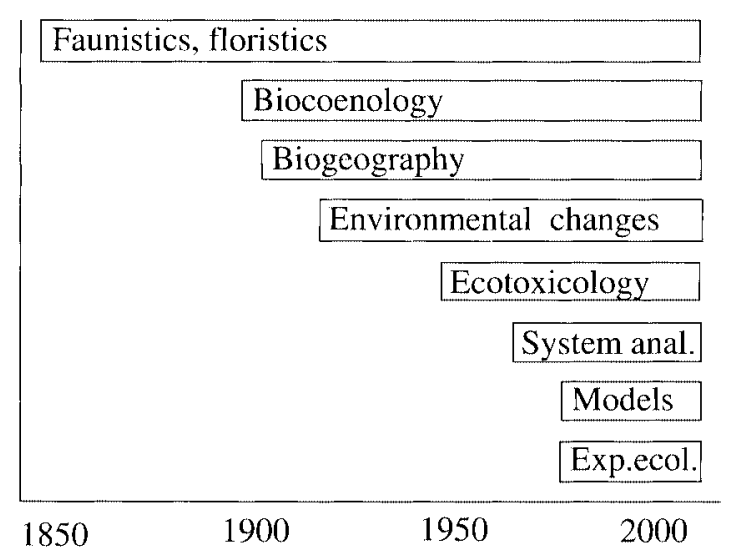

Fig. 4. General trends in Finnish brackish-water biology in 1850-2000. 


\section{REFERENCES}

Aho, I. 1968. Förekomst av kvicksilver i åländsk gädda. Medd. Husö biol. stat., 13, 5-13.

Andersin, A.-B., Lassig, J., Parkkonen, L. \& Sandler, H. 1978. The decline of macrofauna in the deeper parts of the Baltic proper and the Gulf of Finland. Kieler Meeresforsch., Sonderh., 4, 23-52.

Bagge, P. 1969. Effects of pollution on estuarine ecosystems. I. Effects of effluents from woodprocessing industries on the hydrography, bottom and fauna of Saltkällefjord (W. Sweden). Merentutkimuslait. Julk./Havsforskningsinst. Skr., 228, 3-118.

Bagge, P. \& Salo, A. 1967. Biological Detectors of Radioactive Contamination in the Baltic. Institute of Radiation Physics, Helsinki. Rep. SFL-A9.

Bagge, P. \& Voipio, A. 1967. Disturbed bottom and hydrographic conditions in some coastal areas of Finland. I. Loviisa. Merentutkimuslait. Julk./Havsforskningsinst. Skr., 223, 3-12.

Bagge, P., Jumppanen, K., Leppäkoski, E. \& Tulkki, P. 1965. Bottom fauna of the Finnish southwestern archipelago. III. The Lohm area. Ann. Zool. Fennica, 2, 38-52.

BALTIC - Baltic Marine Environment Database. 2001. http://otatrip.hut.fi/vtt/baltic/search.html (Jan. 21, 2001).

Bonsdorff, E. 1980. Macrozoobenthic recolonization of a dredged brackish water bay in SWFinland. Ophelia, Suppl. 1, 145-155.

Bonsdorff, E. \& Österman, C.-S. 1985. The establishment, succession and dynamics of a zoobenthic community - an experimental study. In Proceedings of the 19th European Marine Biology Symposium (Gibbs, P. E., ed.), pp. 287-297. Cambridge University Press.

Bonsdorff, E., Karlsson, O. \& Leppäkoski, E. 1984. Ecological changes in the brackish water environment of the Finnish west coast caused by engineering works. Ophelia, Suppl. 3, 33-44.

Bonsdorff, E., Blomqvist, E. M. \& Pearson, T. H. 1990. Zoobenthos, fish, and birds in a brackish archipelago area - trophic interactions in time and space. In Trophic Relationships in the Marine Environment (Barnes, M. \& Gibson, R. N., eds.), pp. 389-403. Aberdeen University Press.

Cajander, A. H. 1869. Bidrag till kännedomen om sydvestra Finlands krustaceer. Not. Sällsk. Fauna Flora Fennica Förh., 10, 371-376.

Fagerholm, H.-P. 1975. The effects of ferry traffic on the rocky shore macrofauna in the southern Åland archipelago: 1. The Cladophora zone. Merentutkimuslait. Julk. / Havsforskningsinst. Skr., 239, 331-337.

Gadd, P. A. 1769. Dissertatio gradualis, sistens insecta, piscatoribus in maritimis Finlandiae oris noxia. Åbo.

Haahtela, I. 1964. Havaintoja Perämeren selkärangattomista. Luonnon Tutkija, 68, 162-166.

Haahtela, I. 1970. Productivity and pollution on the Baltic coasts of Finland. Mar. Poll. Bull., 1, 8-9.

Haahtela, I. 1988. The role of Sven Ekman, Adolf Remane, Carl Schlieper and Sven G. Segerstråle in Baltic biology. Kieler Meeresforsch., Sonderh. 6, 18-32.

Hällfors, G., Kangas, P. \& Lappalainen, A. 1975. Littoral benthos of the northern Baltic Sea. III. Macrobenthos of the hydrolittoral belt of filamentous algae on rocky shores in Tvärminne. Int. Rev. ges. Hydrobiol., 60, 313-333.

Hällfors, G., Viitasalo, I. \& Niemi, A. 1987. Macrophyte vegetation and trophic status of the Gulf of Finland - a review of Finnish investigations. Meri, 13, 111-158.

Halme, E. 1944. Planktologische Untersuchungen in der Pojo-Bucht und angrenzenden Gewässern. I. Milieu und Gesamtplankton. Ann. Zool. Soc. Vanamo, 10 (2).

Halme, E. 1958. Planktologische Untersuchungen in der Pojo-Bucht und angrenzenden Gewässern. IV. Zooplankton. Ann. Zool. Soc. Vanamo, 19 (3). 
Hamel, N. 1852. Ueber das Project: Austern, wie auch Hummern, Seekrebse, Krabben und Miesmuscheln im Finnischen Meerbusen zu ziehen. Bull. Phys.-Math. Acad. Imp. Sci. Saint-Pétersbourg, 10 (18-20), 308-318.

Häyrén, E. 1900. Längs-zonerna i Ekenäs skärgård. Geogr. Fören. Finl. Tidskr., 12, 222-234.

Häyrén, E. 1910. Über den Saprophytismus einiger Enteromorpha-Formen. Medd. Soc. Fauna Flora Fennica, 36, 157-161.

Häyrén, E. 1921. Studier öfver föroreningens inflytande på strändernas vegetation och flora i Helsingfors hamnområde. Bidr. känned. Finlands Natur Folk., 80 (3).

Häyrén, E. 1923. Föroreningen och strandvegetationen i Helsingfors hamnområde. Svensk Bot. Tidskr., 17, 62-68.

Häyrén, E. 1928. Algen aus der Gegend von Björneborg. Mem. Soc. Fauna Flora Fennica, 4, 185-192.

Häyrén, E. 1931. Algenfunde aus der Meeresufern von Brahestad. Mem. Soc. Fauna Flora Fennica, 7, 174-178.

Häyrén, E. 1938. Einige Algen aus dem Meere bei der Stadt Kemi, Ostrobothnia borealis. Mem. Soc. Fauna Flora Fennica, 14, 128-129.

Hela, I. 1975. Meri. Meri, 1, 7-8.

Hellén, W. 1919a. Zur Kenntnis der Amphipoden-Fauna Finnlands. Medd. Soc. Fauna Flora Fennica, 45, 131-138.

Hellén, W. 1919b. Zur Kenntnis der Isopoden-Fauna Finnlands. Medd. Soc. Fauna Flora Fennica, 45, 124-131.

Hisinger, E. V. E. 1857. Flora Fagervikiensis. Not. Sällsk. Fauna Flora Fennica Förh., 3.

Ilus, E. 1996. Finnish Centre for Radiation and Nuclear Safety. Meri, 26, 12-13.

Jansson, B.-O. 1972. Ecosystem approach to the Baltic problem. Bull. Ecol. Res. Committee NFR, 16.

Järvenpää, T., Tillander, M. \& Miettinen, J. 1970. Methyl-mercury: Half-time of elimination in flounder, pike and eel. Suomen Kemistilehti, B 43, 439-442.

Jylhä-Pyykönen, A. 1978. Den brackvattensbiologiska forskningen i Finland åren 1953-1975. M.Sc. Thesis, Department of Biology, Åbo Akademi University.

Jylhä-Pyykönen, A. 1981. Biological research in the Finnish coastal waters. Nordecol, 13, 6-10.

Kangas, P. 1996. Marine monitoring and research in the former Water and Environment Research Institute. Meri, 26, 13-15.

Karling, T. G. 1931. Untersuchungen über Kalyptorhynchia (Turbellaria Rhabdocoela) aus dem Brackwasser des Finnischen Meerbusens. Acta Zool. Fennica, 11, 1-66.

Karppinen, E. \& Kairasuo, I. 1961. Über das Vorkommen der Wollhandkrabbe, Eriocheir sinensis Milne-Edw., an der Küste Finnlands. Arch. Soc. Vanamo, 15, 39-43.

Klingstedt, F. W. 1907. Beiträge zur Kenntnis der Oscillatoriaceen Finnlands. Medd. Soc. Fauna Flora Fennica, 33, 113-117.

Knipovich, N. M. 1909. Report about the work carried out by N. M. Knipovich and S. A. Pavlovich in summer 1908, aiming at the collection of marine fauna for the Zoological Museum of the Academy of Science. Ezh. Zool. muz. imp. A. N., 14 (3-4), 131-145 (in Russian).

Koli, L. 1961. Die Molluskenfauna des Brackwassergebietes bei Tvärminne, Südwestfinnland. Ann. Zool. Soc. Vanamo, 22 (5), 1-22.

Kolkwitz, R. \& Marsson, M. 1902. Grundsätze für die biologische Beurtheilung des Wassers nach seiner Flora und Fauna. Mitt. Kgl. Prüfungsanst. Wasserversorg. Abwasserbeseit. Berlin, 1, 33-72.

Krok, T. O. B. N. 1869. Bidrag till kännedom om alg-floran i inre Östersjön och Bottniska viken. Öfvers. K. Vetensk. Akad. Förh., 26, 67-92.

Laakso, M. 1965. The bottom fauna in the surroundings of Helsinki. Ann. Zool. Fennica, 2, 19-37.

Lagerspetz, K. 1955. Physiological studies on the brackish water tolerance of some species of Daphnia. Arch. Soc. Vanamo, Suppl. 9, 138-143. 
Laihonen, P., Lietzén, E. \& Vuorinen, I. 1985. Fouling-ilmiön esiintyminen ja torjunta Suomen voimaloissa 1984. Turun yliopiston Biol. lait. julk., 10 (in Finnish with English summary).

Lassig, J. 1965. The distribution of marine and brackishwater lamellibranchs in the northern Baltic area. Comm. Biol. Soc. Sci. Fennica, 28 (5), 1-41.

Lassig, J. \& Niemi, A. 1973. Amounts of chlorophyll $a$ in the Baltic during June and July 1969 and 1970. Oikos, Suppl. 15, 34-42.

Leegaard, C. 1920. Microplankton from the Finnish waters during the month of May 1912. Acta Soc. Sci. Fennica, 48, 1-44.

Lehmusluoto, P. \& Pesonen, L. 1973. Eutrophication in the Helsinki and Espoo sea areas measured as phytoplankton primary production. Oikos, Suppl. 15, 202-208.

Leikola, A. 1980. J. A. Palmén - Suomen eläintieteen suuri uudistaja. Luonnon Tutkija, 84, 200207 (in Finnish with English summary).

Leppäkoski, E. 1969. Transitory return of the benthic fauna of the Bornholm basin, after extermination by oxygen insufficinecy. Cah. Biol. Mar., 10, 163-172.

Leppäkoski, E. 1971. Benthic recolonization of the Bornholm basin (Southern Baltic) in 1969-71. Thalassia Jugosl., 7, 171-179.

Leppäkoski, E. 1973. Effects of an oil spill in the Northern Baltic. Mar. Poll. Bull., 4, 93-94.

Leppäkoski, E. 1975. Assessment of degree of pollution on the basis of macrozoobenthos in marine and brackish-water environments. Acta Acad. Aboensis, Ser. B, 35 (2).

Leppäkoski, E. 1984. Introduced species in the Baltic Sea and its coastal ecosystems. Ophelia, Suppl. 3, 123-135.

Leppäkoski, E. \& Lindström, L. 1978. Recovery of benthic macrofauna from chronic pollution in the sea area off a refinery plant, southwest Finland. J. Fish. Res. Bd. Can., 35, 766-775.

Leppäkoski, E. \& Rönnberg, O. 1988. History of benthic research in the Northern Baltic Sea: From description to prediction. Kieler Meeresforsch., Sonderh. 6, 7-17.

Levander, K. M. 1891. Mikrofaunistiska anteckningar. Medd. Soc. Fauna Flora Fennica, 17, 129-143.

Levander, K. M. 1899. Materialien zur Kenntniss der Wasserfauna in der Umgebung von Helsingfors, mit besonderer Berücksichtigung der Meeresfauna. III. Acta Soc. Fauna Flora Fennica, 17 (4), 1-23.

Levander, K. M. 1900a. Über das Herbst- und Winter-Plankton im Finnischen Meerbusen und in der Ålands-See 1898. Acta Soc. Fauna Flora Fennica, 18 (5), 1-25.

Levander, K. M. 1900b. Zur Kenntnis des Lebens in den stehenden Kleingewässern auf den Skäreninseln. Acta Soc. Fauna Flora Fennica, 18 (6), 1-107.

Levander, K. M. 1901a. Übersicht der in der Umgebung von Esbo-Löfö im Meerwasser vorkommenden Thiere. Acta Soc. Fauna Flora Fennica, 20 (6), 1-20.

Levander, K. M. 1901b. Zur Kenntnis des Planktons und der Bodenfauna einiger seichten Brackwasserbuchten. Acta Soc. Fauna Flora Fennica, 20 (5), 1-34.

Levander, K. M. 1913. Till kännedom om planktonbeskaffenheten i Helsingfors inre hamnar. Med. Soc. Fauna Flora Fennica, 39, 26-36.

Levander, K. M. 1915. Zur Kenntnis der Bodenfauna und des Planktons der Pojowiek. Fennia, 35 (2), 1-39.

Levander, K. M. \& Purasjoki, K. J. 1947. Plankton gesammelt in den Jahren 1899-1910 an den Küsten Finnlands. Finnl. Hydrogr.-Biol. Unters., 11.

Lindberg, H. 1937. Ökologische Studien über die Coleopteren- und Hemipteren-Fauna im Meere in der Pojo-Wiek und im Schärenarchipel von Ekenäs in Südfinnland. Acta Soc. Fauna Flora Fennica, 60, 516-572.

Lindberg, H. 1948. Zur Kenntnis der Insektenfauna im Brackwasser des Baltischen Meeres. Comm. Biol. Soc. Sci. Fennica, 10 (9).

Lindén, O. 1974. Effects of oil spill dispersants on the early development of Baltic herring. Ann. Zool. Fennica, 11, 141-148. 
Lindström, G. 1855. Bidrag till kännedomen om Östersjöns invertebrat-fauna. Öfv. Kongl. Vetenskaps-akad. förh., 12, 49-73.

Linko, R., Kaitaranta, J., Rantamäki, P. \& Eronen, L. 1974. Occurrence of DDT and PCB compounds in Baltic herring and pike from Turku archipelago. Env. Poll., 7, 193-207.

Luther, A. 1904. Die Eumesostominen. Zeitschr. wiss. Zool., 77.

Luther, A. 1957. Tvärminne zoologiska station. Acta Soc. Fauna Flora Fennica, 73.

Luther, H. 1951a. Verbreitung und Ökologie der höheren Wasserpflazen im Brackwasser der Ekenäs-Gegend im Süd-Finnland. I. Allgemeiner Teil. Acta Bot. Fennica, 49.

Luther, H. 1951b. Verbreitung und Ökologie der höheren Wasserpflazen im Brackwasser der Ekenäs-Gegend im Süd-Finnland. II. Spezieller Teil. Acta Bot. Fennica, 50.

Luther, H. 1982. The first half century of limnology in Finland. Hydrobiologia, 86, 1-7.

Luther, H., Hällfors, G., Lappalainen, A. \& Kangas, P. 1975. Littoral benthos of the northern Baltic Sea. I. Introduction. Int. Rev. ges. Hydrobiol., 60, 289-296.

Mankki, J. \& Vauras, J. 1974. Littoral fish populations after an oil tanker disaster in the Finnish SW archipelago. Ann. Zool. Fennica, 11, 120-126.

Mathiesen, L. 1965. On Leathesia difformis and other algae from the Alland SW-archipelago. Mem. Soc. Fauna Flora Fennica, 41, 71-77.

Melvasalo, T., Pesonen, L., Varmo, R. \& Viljamaa, H. 1975. Inshore effects of pollution on the biota of the Baltic, southern Finland. Verh. Int. Verein. Limnol., 19, 2340-2353.

Mölder, K. 1943. Studien über die Ökologie und Geologie der Bodendiatomeen in der Pojo-Bucht. Ann. Bot. Soc. Zool.-Bot. Vanamo, 18 (2).

Naylor, E. \& Haahtela, I. 1966. Habitat preferences and interspersion of species within the superspecies Jaera albifrons Leach (Crustacea: Isopoda). J. Anim. Ecol., 35, 209-216.

Naylor, E. \& Haahtela, I. 1967. Quantitative ecological distribution of the Jaera albifrons group of species in the Baltic. Ophelia, 4, 19-27.

Niemi, Å. 1972a. Effects of toxicants on brackish-water phytoplankton assimilation. Comm. Biol. Soc. Sci. Fennica, 55, 1-19.

Niemi, A. 1972b. Observations on phytoplankton in eutrophied and non-eutrophied archipelago waters of the southern coast of Finland. Mem. Soc. Fauna Flora Fennica, 48, 63-74.

Niemi, A. 1973. Ecology of phytoplankton in the Tvärminne area, SW coast of Finland. I. Dynamics of hydrography, nutrients, chlorophyll $a$ and phytoplankton. Acta Bot. Fennica, 100.

Niemi, A. 1975. Ecology of phytoplankton in the Tvärminne area, SW coast of Finland. II. Primary production and environmental conditions in the archipelago and the sea zone. Acta Bot. Fennica, 105.

Nordenskiöld, A. E. \& Nylander, A. A. 1856. Finlands mollusker. Helsingfors.

Nordqvist, O. 1890. Bidrag till kännedomen om Bottniska vikens och norra Östersjöns evertebratfauna. Medd. Soc. Fauna Flora Fennica, 17, 83-128.

Nylander, A. A. 1844. Stirpes cotyledonae paroeciae Pojo. Diss., Helsingfors.

Nylander, W. \& Saelan, T. 1859. Herbarium Musei Fennici. Helsingfors.

Palmén, E. 1955. Diel periodicity of pupal emergence in natural populations of some chironomids (Diptera). Ann. Zool. Soc. Vanamo, 17 (3), 1-30.

Pelkonen, K. \& Tulkki, P. 1972. The Palva oil tanker disaster in the Finnish SW archipelago. III. The littoral fauna of the oil polluted area. Aqua Fennica, 1972, 129-136.

Persson, P.-E., Sivonen, K., Keto, J., Kononen, K., Niemi, M. \& Viljamaa, H. 1984. Potentially toxic blue-green algae (cyanobacteria) in Finnish natural waters. Aqua Fennica, 14, $147-$ 154.

Purasjoki, K. 1953. Beobachtungen über die Einwirkung gesteigerten Salzgehalts auf das Auftreten einiger marinen Zooplanktonarten ausserhalb Helsinki. Arch. Soc. Vanamo, 8, 101-104.

Rasmussen, E. 1977. Danish brackish-water fauna - 200 years' research. Folia Limnol. Scand., 17, 91-100. 
Rautiainen, H. \& Ravanko, O. 1972. The epiphytic diatom flora of the benthic macrophyte communities on rocky shores in the southwestern archipelago of Finland, Seili Islands. Nova Hedwigia, 23, 827-842.

Ravanko, O. 1968. Macroscopic green, brown and red algae in the southwestern archipelago of Finland. Acta. Bot. Fennica, 79, 1-50.

Ravanko, O. 1972. The physiognomy and structure of the benthic macrophyte communities on rocky shores in the southwestern archipelago of Finland (Seili islands). Nova Hedwigia, 23, 363-403.

Reuter, J. 1961. Einige faunistische und ökologische Beobachtungen über Felsentümpel-Ziliaten. Acta Zool. Fennica, 99, 1-42.

Rönnberg, O. 1975. The effects of ferry traffic on rocky shore vegetation in the southern Åland archipelago. Merentutkimuslait. Julk./Havsforskningsinst. Skr., 239, 325-330.

Rönnberg, O. 1981. Traffic effects on rocky-shore algae in the Archipelago Sea, SW Finland. Acta Acad. Aboensis, Ser. B 41 (3).

Särkkä, J. 1967. Pohjaeläimistö likaantuneiden jokien suualueilla. Vesitalous, 1967 (3), 1-4 (in Finnish with English summary).

Sarvala, J. 1971. Ecology of Harmothoe sarsi (Malmgren) (Polychaeta, Polynoidae) in the northern Baltic area. Ann. Zool. Fennici, 8, 231-309.

Sarvala, J. 1992. Trends in Finnish limnology during 1940-1989. Hydrobiologia, 243/244, 1-19.

Segerstråle, S. G. 1927. Kommt bei Tellina baltica eine Wanderung aus der Uferzone vor? Comm. Biol. Soc. Sci. Fennica, 2 (11), 1-8.

Segerstråle, S. G. 1928. Quantitative Studien über den Tierbestand des Fucus-Vegetation in der Schären von Pellinge an der Südküste Finnlands. Comm. Biol. Soc. Sci. Fennica, 3 (2), $1-14$.

Segerstråle, S. G. 1933a. Studien über die Bodentierwelt in südfinnländischen Küstengewässern. I. Untersuchungsgebiete, Methodik und Material. Comm. Biol. Soc. Sci. Fennica, 4 (8), $1-64$.

Segerstråle, S. G. 1933b. Studien über die Bodentierwelt in südfinnländischen Küstengewässern. II. Übersicht über die Bodentierwelt, mit besonderer Berücksichtigung der Produktionsverhältnisse. Comm. Biol. Soc. Sci. Fennica, 4 (9), 1-77.

Segerstråle, S. G. 1937. Studien über die Bodentierwelt in südfinnländischen Küstengewässern. III. Zur Morphologie und Biologie des Amphipoden Pontoporeia affinis, nebst einer Revision der Pontoporeia-Systematik. Comm. Biol. Soc. Sci. Fennica, 7 (1), 1-181.

Segerstråle, S. G. 1944. Weitere Studien über die Tierwelt der Fucus-Vegetation an der Südküste Finnlands. Comm. Biol. Soc. Sci. Fennica, 9 (4), 1-28.

Segerstråle, S. G. 1950. The amphipods on the coasts of Finland - some facts and problems. Comm. Biol. Soc. Sci. Fennica, 10 (14), 1-28.

Segerstråle, S. G. 1957a. Baltic Sea. Treatise on marine ecology and paleoecology (Hedgpeth, J. W., ed.). Mem. Geol. Soc. Am., 67, 751-800.

Segerstråle, S. G. 1957b. On the immigration of the glacial relicts of Northern Europe, with remarks on their prehistory. Comm. Biol. Soc. Sci. Fennica, 16 (16), 1-117.

Segerstråle, S. G. 1964a. Literature on marine biology in the Baltic area published in the years 1953-1962. Comm. Biol. Soc. Sci. Fennica, 27, 1-44.

Segerstråle, S. G. 1964b. Marine zoology in the Baltic area in 1953-1962. Oceanogr. Mar. Biol. Ann. Rev., 2, 373-392.

Segerstråle, S. G. 1975. Literature on marine biology in the Baltic area published in the years 1963-1972. Comm. Biol. Soc. Sci. Fennica, 77, 1-80.

Segerstråle, S. G. 1976. Recent trends in Baltic marine biological research. Oceanogr. Mar. Biol. Ann. Rev., 14, 347-369.

Segerstråle, S. G. 1982. The immigration of glacial relicts into Northern Europe in the light of recent geological research. Fennia, 160, 303-312. 
Siemaschko, J. v. 1847. Beitrag zur Kenntnis der Konchylien Russlands. Bull. Soc. imp. Nat. Moscou, 20 (1), 93-131.

Sjöblom, V. 1955. Bottom fauna. The summer cruise with m/s Aranda in the northern Baltic 1954. Merentutkimuslait. Julk./Havsforskningsinst. Skr., 166, 34-40.

Söderqvist, T. 1986. The Ecologists. From Merry Naturalists to Saviours of the Nation. Stockholm.

Strömfelt, H. F. G. 1884. Om algvegetationen i Finlands sydvestra skärgård. Bidr. känned. Finlands Natur Folk, 39, 121-140.

Tulkki, P. 1960. Studies on the bottom fauna of the Finnish southwestern archipelago. I. Bottom fauna of the Airisto Sound. Ann. Zool. Soc. 'Vanamo', 21 (3), 1-26.

Tulkki, P. 1964. Studies on the bottom fauna of the Finnish southwestern archipelago. II. Bottom fauna of the polluted harbour area of Turku. Arch. Soc. 'Vanamo', 18, 175-188.

Tulkki, P. 1965. Disappearance of the benthic fauna from the Basin of Bornholm (Southern Baltic), due to oxygen deficiency. Cah. Biol. Mar., 6, 455-463.

Tulkki, P. 1969. Die Bodentiere als Indikatororganismen für Verunreinigung in einem Brackwassergebiet. Limnologica (Berlin), 7 (1), 79-83.

Ulvinen, A. 1937. Untersuchungen über die Strand- und Wasserflora des Schärenhofes am mittleren Mündungsarm des Flusses Kymijoki in Südfinnland. Ann. Bot. Soc. 'Vanamo', 8.

Välikangas, I. 1926. Planktologische Untersuchungen im Hafengebiet vor Helsingfors. I. Acta Zool. Fennica, 1.

Välikangas, I. 1933. Über die Biologie der Ostsee als Brackwassergebiet. Verh. Int. Ver. theor. angew. Limnol., 6, 62-112.

Viitasalo, M. 1992. Mesozooplankton of the Gulf of Finland and northern Baltic Proper - review of monitoring data. Ophelia, 35, 147-168.

Vuorinen, I. \& Ranta, E. 1987. Dynamics of marine mesozooplankton at Seili, northern Baltic Sea, in 1967-1975. Ophelia, 28, 31-48.

Wikgren, B.-J. 1952. The influence of Trematode infection on the Gastropod fauna of shores and rock pools. Oikos, 4, 172-177.

Wikgren, B.-J. 1996. Biologins historia. Åbo Akademi University Press, Åbo.

Wuorentaus, Y. 1913. Tietoja Pohjanlahden rannikkoplanktonista. Medd. Soc. Fauna Flora Fennica, 39, 15-25.

\section{"INSECTA PISCATORIBUS ... NOXIA'ST" ÖKOLOOGILISTE MUDELITENI - SOOME RIIMVEEBIOLOOGIA AJALUGU}

\section{Erkki LEPPÄKOSKI}

On antud ülevaade Soome riimveebioloogiast alates C. v. Linné aegadest kuni 1990. aastani. Põhjaelustiku uuringud algasid 19. sajandi keskel. 1920. aastatel alustas S. G. Segerstråle põisadru vööndi ja pehme põhja fauna uuringuid. Riimveebioloogia ökologiseerus järk-järgult. 1960. aastatel suurenes oluliselt merebioloogiliste tööde maht ja mitmekesisus. Areng toimub rakenduslikkuse tähtsustumise ning modelleerimise suunas. 